\title{
PERGURUAN TINGGI BERBASIS PESAN'TREN: Menggagas Interkoneksi Agama Dan Sains
}

\author{
Muhammad Munif \\ Universitas Nurul Jadid Paiton Probolinggo \\ m.munifmpdi@gmail.com \\ Hasan Baharun \\ Universitas Nurul Jadid Paiton Probolinggo \\ ha54nbaharun@gmail.com
}

\begin{abstract}
This research presents about college strategy based on pesantren in realizing the interconnection of religion and science in Sekolah Tinggi Tekhnologi dan Sekolah Tinggi Ilmu Kesehatan Nurul Jadid Paiton Probolinggo. Interconnection of religion and science as a concept that offers for the relationship between discipline of science of religion and general science. The estuary of the interconnection of religion and science is to unite and make a connection between religious education and science. This research uses qualitative approach of case study type. The results show that; 1) The interconnection strategy of religion and science conducted by Sekolah Tinggi Tekhnologi (STT) Nurul Jadid and Sekolah Tinggi Ilmu Kesehatan (STIKes) Nurul Jadid Paiton Probolinggo include; internal and external environment analysis, vision and mission determination, mindset change, curriculum development with integration pattern, strengthening of buman resource quality, formation
\end{abstract}


of religious culture. 2) the impact of the interconnection of religion and science is; the inclusive attitude in understanding the development of science and religion, has a global perspective, the achievement of the vision and mission of the institution as the leader of the vision and mission of pesantren.

Keywords : college, pesantren, interconnection

\begin{abstract}
Abstrak
Penelitian ini menyajikan tentang strategi perguruan tinggi berbasis pesantren dalam menggagas interkoneksi agama dan sains di Sekolah Tinggi Tekbnologi dan Sekolah Tinggi Ilmu Kesehatan Nurul Jadid Paiton Probolinggo. Interkoneksi merupakan konsep yang menawarkan agar hubungan antara displin ilmu menjadi semakin terbuka dan cair. Muara dari interkoneksitas agama dan sains merupakan usaba untuke menyatukan dan menjadikan sebuab keterhubungan antara pendidikan agama dengan sains. Penelitian ini menggunakan pendekatan kualitatif jenis studi kasus. Hasil penelitian menunjukkan bahwa; 1) Strategi interkoneksi agama dan sains yang dilakukan oleh Sekolah Tinggi Tekhnologi (STT) Nurul Jadid dan Sekolah Tinggi Ilmu Kesehatan (STIKes) Nurul Jadid Paiton Probolinggo meliputi ; Analisis internal dan eksternal, penetapan visi dan misi, mindset change (perubahan pola pikir), penguatan kualitas sumber daya manusia dan pembentukan budaya relegius. 2) Implikasi dari interkoneksi agama dan sains di STT dan STIKes Nurul Jadid adalab; labirnya sikap inklusif dalam memahami perkembangan agama dan sains, memiliki perspektif global dan tercapainya visi dan misi institusi sebagai pengemban amanat pesantren
\end{abstract}

Kata Kunci: Perguruan tinggi, pesantren, interkoneksi

\title{
A. Pendahuluan
}

Pesantren merupakan salah satu lembaga pendidikan yang sangat besar pengaruh dan peranannya dalam pendidikan moral bangsa. Sebagai lembaga yang berfokus pada tafaqquh fi al$d i{ }^{1}$, yaitu lembaga pendidikan yang memberikan pengajaran dan

${ }^{1}$ Ahmad Muthohar, Ideologi Pendidikan Pesantren : Pesantren di Tengah Arus Ideologi-ideologi Pendidikan, (Semarang: Pustaka Rizki Putra, 2007), 17. 
pendidikan ilmu-ilmu atau syari'at agama Islam, pesantren hingga sekarang mempunyai daya tarik tersendiri, baik dari sosok luarnya, kehidupan sehari-harinya, potensi dirinya, isi pendidikannya, system dan metodenya, semua menarik untuk dikaji.

Pondok pesantren merupakan lembaga pendidikan tradisional Islam untuk memahami, menghayati, dan mengamalkan ajaran agama Islam dengan menekankan pentingnya moral agama Islam sebagai pedoman hidup bermasyarakat sehari-hari ${ }^{2}$. Sebagai sebuah lembaga pendidikan yang berangkat dari nilai akar budaya bangsa Indonesia, pondok pesantren didirikan dalam rangka dakwah dan penegakan agama Islam (iqamatuddin) di muka bumi ini $^{3}$.

Pondok pesantren adalah lembaga pendidikan Islam yang tumbuh serta diakui oleh masyarakat sekitarnya, dengan model sistem asrama yang mana santri-santrinya menerima pendidikan agama melalui sistem pengajaran di madrasah/sekolah yang sepenuhnya berada di bawah kepemimpinan seorang atau beberapa orang kyai (pengasuh) dengan ciri-ciri khas yang bersifat kharismatik, inspiratif dan transformative ${ }^{4}$.

Secara historis, keberdaan pondok pesantren di Indonesia tidak hanya identik dan sama dengan makna keislaman sebagaimana kita ketahui, tetapi juga mengandung makna keaslian Indonesia 5 . Dengan segala dinamikanya, pondok pesantren dipandang sebagai suatu lembaga pendidikan yang bertugas memberikan pendidikan, pengkaderan dan dakwah Islam guna terciptanya perubahan di masyarakat.

Dalam perjalanannya, pondok pesantren pada umumnya tidak merumuskan tujuan pendidikannya secara rinci dan dijabarkan

\footnotetext{
${ }^{2}$ Hasbullah, Kapita Selesta Pendidikan Islam di Indonesia, (Jakarta : PT. Raja Grafindo Persada, 1996), 44.

3 Abdul Qadir Djaelani, Peran Ulama dan Santri dalam Perjuangan Politik di Indonesia, (Surabaya : PT. Bina Ilmu, 1994), 7.

${ }^{4}$ Djamaluddin dan Abdullah Aly, Kapita Selekta pendidikan Islam, (Bandung : Pustaka Setia, 1999), 99.

5 Abudin Nata, Sejarah Pertumbuhan dan Perkembangan Lembaga-lembaga Pendidikan Islam di Indonesia, (Jakarta : Grasindo, 2001), 105.
} 
dalam sebuah sistem pendidikan yang lengkap dan konsisten sebagaimana yang tertulis dalam kurikulum lembaga pendidikan formal di berbagai jenjang pendidikan. Menurut Zamakhsari Dhofier (1982 : 21) tujuan pendidikan di pondok pesantren tidak semata-mata untuk memperkaya pikiran murid dengan penjelasan-penjelasan, tetapi untuk meninggikan moral, melatih dan mempertinggi semangat, menghargai nilai-nilai spiritual dan kemanusiaan, mengajarkan sikap dan tingkah laku yang jujur dan bermoral, dan menyiapkan para murid untuk hidup sederhana dan bersih hati. Dari rumusan tujuan pendidikan di pondok pesantren tersebut di atas, tampak jelas bahwa pendidikan pesantren sangat menekankan pentingnya tegaknya Islam di tengah-tengah kehidupan sebagai sumber utama moral yang merupakan kunci keberhasilan hidup bermasyarakat.

Mengingat pentingnya pesantren dalam menciptakan dan membentuk karakter muslim yang memiliki integritas keislaman sebagaimana tersebut di atas, maka dewasa ini pesantren mulai berlomba untuk berbenah diri dengan mengadakan reformulasi sistem pendidikannya ke arah yang lebih mapan dengan prinsip peningkatan kualitas dan mutu pendidikannya yang disesuaikan dengan tuntutan masyarakan dan zaman yang melingkupinya.

Terlebih, belakangan ini pesantren telah menuju suatu perkembangan yang luar biasa, dengan berdirinya perguruan tinggi di pesantren. Sebenarnya antara perguruan tinggi dan pesantren tidak ada perbedaan baik secara instituasional, filosofis dan kultural. Sebelumnya dipahami bahwa pesantren merupakan fenomena yang bercorak tradisional dan berada di pedesaan. Sedangkan perguruan tinggi terdapat di perkotaan dan bersifat modern. Perguruan tinggi memiliki keunggulan rasionalitas, sementara pesantren menekankan pada aspek spiritual dan lemah secara intelektual. Pesantren dan perguruan tinggi adalah lembaga pendidikan yang memiliki perbedaan mendasar, tetapi saat ini mulai saling mendekat. Barangkali inilah yang dikatakan sebagai fenomena paca modern, di mana berkembang suatu realitas dunia 
yang mulai memperlihatkan suatu unitas, tetapi di dalamnya ada pluralitas.

Hal inilah yang terjadi di pondok pesantren Nurul Jadid Paiton Probolinggo, di mana pesantren ini memiliki sejumlah perguruan tinggi yang bertujuan untuk mempersiapkan santrinya ready for use ketika berhadapan dengan masyarakat kelak, seperti Sekolah Tinggi Tekhnologi (STT Nurul Jadid) dan Sekolah Tinggi Ilmu Kesehatan (STIKes Nurul Jadid) Paiton Probolinggo yang memiliki karakteristik keilmuan masing-masing pada pengembangannya.

Sekolah Tinggi Tekhnologi (STT) dan Sekolah Tinggi Ilmu Kesehatan (STIKes) Nurul Jadid Paiton Probolinggo sebagai situs dalam penelitian ini menarik untuk dikaji, karena secara nyata dua lembaga pendidikan yang berada di bawah naungan pesantren tersebut berorientasi pada pengembangan sains, dan di sisi lain, lembaga tersebut juga diharuskan untuk mengembangkan agama sebagai konsekwensi logis dari lingkungan yang mengitarinya, yaitu dunia pendidikan pesantren.

Sebagai lembaga pendidikan yang berada di bawah naungan pesantren, tentunya Sekolah Tinggi Tekhnologi (ST'T) Nurul Jadid dan Sekolah Tinggi Ilmu Kesehatan (STIKes) Nurul Jadid Paiton Probolinggo memiliki ciri khas pengembangan disiplin keilmuan tersendiri, khususnya dalam pelaksanaan Tri Dharma Perguruan Tinggi, yaitu pendidikan, penelitian dan pengabdian kepada masyarakat.

Dalam kegiatan pendidikan, penelitian dan pengabdian kepada masyarakat pada masing-masing perguruan tinggi yang berada di bawah naungan yayasan Nurul Jadid sama-sama memiliki orientasi pengembangan disiplin keilmuan yang sama. STT Nurul Jadid dan STIKes Nurul Jadid, yang mana lembaga tersebut intens melaksanakan Tri Dharma Perguruan Tingginya lebih memfokuskan kajiannya pada pengembangan Sains dan Agama, untuk melahirkan lulusan yang memiliki wawasan keilmuan yang multi interdisipliner, sebagai perpaduan antara pengembangan 
keilmuan yang ada di perguruan tinggi dan pengembangan keagamaan, karena tuntutan lingkungan institusi perguruan tinggi yang berada di dalam lingkungan pesantren.

Dalam realitas kehidupan masyarakat luas hingga kini, masih kuat pemikiran bahwa "agama" dan "ilmu" adalah dua entitas yang tidak bisa dipertemukan. Keduanya mempunyai wilayah sendirisendiri, terpisah antara satu dan lainnya, baik dari segi objek formal-material, metode penelitian, kriteria kebenaran, peran yang dimainkan oleh ilmuwan maupun status teori masingmasing bahkan sampai ke institusi penyelenggaranya. Dengan ungkapan lain, ilmu tidak peduli agama dan agama tidak peduli ilmu'

Oleh karena itu, Sekolah Tinggi Tekhnologi (ST'T Nurul Jadid) dan Sekolah Tinggi Ilmu Kesehatan (STIKes Nurul Jadid) Paiton Probolinggo sebagai lembaga perguruan tinggi yang berada di lingkungan pesantren harus mampu mengintegrasikan dan mensinergikan antara agama dan sains - termasuk di dalamnya ilmu sosial dan humaniora - sebagai perwujudan pencapaian visi dan misi lembaga. Sains dan agama merupakan dua unit yang berbeda, namun keduanya sama-sama memiliki peranan yang signifikan dalam kehidupan manusia. Dengan lahirnya agama, menjadikan umat manusia memiliki keimanan sehingga menjadikan hidupnya lebih terarah, beretika, bermoral dan beradab. Sementara itu, Sains memberikan banyak pengetahuan bagi manusia. Dengan semakin berkembangnya Sains, akan memajukan dunia dengan berbagai penemuan yang gemilang serta memberikan kemudahan fasilitas yang sangat menunjang keberlangsungan hidup manusia.

Tentunya, untuk mengintegrasikan agama dan sains pada perguruan tinggi yang berada di Pondok Pesantren tidaklah mudah. Wacana tentang integrasi ilmu dan agama telah muncul cukup lama. Meski tak selalu menggunakan kata "integrasi” atau "interkoneksi" secara eksplesit, di kalangan muslim modern

${ }^{6}$ Mulyono, Model Integrasi Sains dan Agama dalam Pengembangan Akademik Keilmuan UIN, dalam Jurnal Penelitian Keislaman, Vol. 7, No. 2, Juni 2011, 321 
gagasan perlunya pemaduan ilmu dan agama, atau akal dan wahyu (iman), telah cukup lama beredar?

Interkoneksi berarti hubungan satu sama lain ${ }^{8}$. Dalam dunia keilmuan, interkoneksi adalah wacana atau model baru dalam dunia pendidikan yang dimaksudkan untuk menawarkan agar hubungan antara displin ilmu menjadi semakin terbuka dan cair?

Pendidikan integrasi-interkoneksi pada hakekatnya merupakan tanggung jawab bersama civitas akademik Perguruan Tinggi. Hal ini dapat terwujud bila seluruh civitas akademik pimpinan, dosen, mahasiswa, stake holders - mempunyai perhatian ke arah itu. Muara dari interkoneksitas agama dan sains merupakan usaha untuk menyatukan dan menjadikan sebuah keterhubungan antara pendidikan agama dengan sains yang dilaksanakan oleh Sekolah Tinggi Tekhnologi (STT Nurul Jadid) dan Sekolah Tinggi Ilmu Kesehatan (STIKes Nurul Jadid) Paiton Probolinggo sebagai lembaga perguruan tinggi yang berada di lingkungan pesantren.

Bertolak dari pentingnya interkoneksitas pendidikan agama dan sais pada perguruan tinggi di pondok pesantren, maka dalam hal ini peneliti tertarik untuk melakukan penelitian tentang Interkoneksi Agama dan Sains pada Perguruan Tinggi di Pondok Pesantren (Studi Kasus di ST'T Nurul Jadid dan STIKes Nurul Jadid Paiton Probolinggo), terkait dengan strategi dan implikasinya.

\section{Pesantren dan Pendidikan Perguruan Tinggi}

Pondok pesantren merupakan lembaga pendidikan Islam yang menempatkan sosok kiai sebagai tokoh sentral dan masjid sebagai pusat lembaganya ${ }^{10}$. Lembaga ini merupakan institusi pendidikan Islam tertua di Indonesia dan sekaligus bagian dari

\footnotetext{
7 Lihat : Zainal Abidin Bagir, dkk., (Eds)., Integrasi Imu dan Agama: Intrepretasi dan Aksi (Bandung: PT Mizan Pustaka Kerjasama dengan UGM dan Suka Press Yogyakarta, 2005), 20.

${ }^{8}$ Departemen Pendidikan Nasional, Kamus Besar Bahasa Indonesia, edisi ke-3, (Jakarta : Balai Pustaka, 2003), 439

${ }_{9}$ M. Amin Abdullah, Islamic Studies dalam Paradigma Integrasi Interkoneksi, (Yogyakarta : SUKA Press, 2006), viii-ix

${ }^{10}$ Dawam Raharjo, Pesantren dan Pembaharuan, (Jakarta: LP3ES, 1995), 87
} 
warisan budaya bangsa (indigenous culture) ${ }^{11}$. Maka, bukanlah kebetulan jika pesantren masih dapat bertahan hingga saat ini.

Kehadiran pesantren tidak dapat dipisahkan dari tuntutan umat. Karena itu, pesantren sebagai lembaga pendidikan selalu menjaga hubungan yang harmonis dengan masyarakat di sekitarnya sehingga keberadaannya di tengah-tengah masyarakat tidak menjadi terasing. Dalam waktu yang sama, segala aktifitasnya pun mendapat dukungan dan apresiasi penuh dari masyarakat sekitarnya. Semua memberi penilaian tersendiri bahwa sistem pesantren adalah merupakan sesuatu yang bersifat "asli" atau "indigenos" Indonesia, sehingga dengan sendirinya bernilai positif dan harus dikembangkan.

Sebagai lembaga pendidikan yang memproses santri menjadi manusia yang bermanfaat dalam kehidupan duniawi dan ukhrawinya, maka pesantren dalam konteks pencapaian tujuan pendidikannya tidak bisa dipisahkan dengan kurikulum yang didesainnya. Oleh karena itu, bukan sesuatu yang naif bila dipandang perlu adanya pengembangan kurikulum pesantren sekaligus upaya mengembangkannya.

Berbicara tentang pengembangan kurikulum, upaya pengembangan kurikulum di pondok pesantren dipandang sangat urgen dan perlu dikembangkan secara berkesinambungan ${ }^{12}$, terutama untuk menghadapi tantangan perubahan zaman sekaligus sebagai antisipasi terhadap segala konsekuensi yang menyertainya. Dengan demikian, pesantren mempunyai potensi besar untuk menjadi lembaga pendidikan ideal yang dapat dijadikan alternatif bagi masyarakat Indonesia.

Agar potensi tersebut benar-benar teraktualisasi menjadi kekuatan nyata, maka pesantren harus berbenah diri dalam

11 Amal Fathullah Zarkasyi, "Pondok Pesantren sebagai Lembaga Pendidikan dan Dakwah”, (Jakarta: Gema Insani Pers, 1998), 171. Lihat juga dalam ; Nurcholish Madjid, Bilik-Bilik Pesantren Sebuah Potret Perjalanan (Jakarta: Paramadina, 1997), 3

12 Dwi Priyanto, Inovasi Kurikulum Pesantren Memproyeksikan Model Pendidikan Alternatif Masa Depan), Ibda ; Jurnal Studi Islam dan Budaya,| Vol. 4 | No. 1 | Jan-Jun 2006 |20-37 
melaksanakan fungsi kependidikannya, terutama berkaitan dengan pengembangan/inovasi kurikulum pendidikan pesantren. Salah satu model pengembangan kurikulum pesantren yang dapat dipertimbangkan implementasinya adalah bertumpu pada tujuan, pengembangan bahan pelajaran, peningkatan proses pembelajaran, dan pengembangan sistem penilaian yang komprehensif.

Sebagai upaya pengembangan pendidikan di pondok pesantren, maka dewasa ini pondok pesantren mengakomodir tuntutan masyarakat dan responsi perkembangan zaman ${ }^{13}$ melalui pendirian lembaga pendidikan tinggi yang ditujukan untuk mempersiapkan santri yang berkarakter, memiliki keilmuan yang multi interdisipliner, sehingga benar-benar siap hidup dan berdakwah di masyarakatnya.

Pendidikan tinggi yang dikembangankan oleh pesantren dalam hal ini adalah pendidikan pada jalur pendidikan formal pada jenjang yang lebih tinggi daripada menengah. Pendidikan Tinggi yang diselenggarakan untuk menyiapkan peserta didik menjadi anggota masyarakat yang memiliki kemampuan akademik dan/ atau profesional untuk dapat menerapkan, mengembangkan dan/atau menciptakan ilmu pengetahuan, teknologi dan/atau kesenian dan dapat dilakukan melalui proses pembelajaran yang mengembangkan kemampuan belajar mandiri.

Perguruan tinggi merupakan salah satu lembaga pendidikan yang secara formal diberi tugas dan tanggung jawab mempersiapkan mahasiswa sesuai dengan tujuan pendidikan nasional. Pendidikan Tinggi adalah pendidikan pada jalur pendidikan sekolah pada jenjang yang lebih tinggi dari pada menengah. Pendidikan Tinggi yang diselenggarakan untuk menyiapkan peserta didik menjadi anggota masyarakat yang memiliki kemampuan akademik dan/ atau profesional untuk dapat menerapkan, mengembangkan dan/atau menciptakan ilmu pengetahuan, teknologi dan/atau

${ }_{13}$ Muhammad Heriyudanta, Modernisasi Pendidikan Pesantren Perspektif Azyumardi Azra, Mudarrisa, Jurnal Kajian Pendidikan Islam, Vol. 8, No. 1, Juni 2016: 145-172, 
kesenian dan dapat dilakukan melalui proses pembelajaran yang mengembangkan kemampuan belajar mandiri.

Perguruan Tinggi merupakan wahana tenaga ahli yang diharapkan mampu mengembangkan ilmu pengetahuan. Sebagai usaha sistematis untuk meningkatkan kualitas sumber daya manusia maka Departemen Pendidikan Nasional telah menetapkan empat kebijakan pokok dalam bidang pendidikan, yaitu (1) pemerataan dan kesempatan; (2) relevansi pendidikan dengan pembangunan; (3) Kualitas pendidikan; dan (4) efisiensi pendidikan. Khusus untuk perguruan tinggi akan lebih diutamakan membahas mengenai relevansi pendidikan dengan pembangunan yang dalam langkah pelaksanaannya dikenal dengan keterkaitan dan kesepadanan (link and macth) ${ }^{14}$.

Upaya menciptakan keterkaiatn dan kesepadanan tersebut mengacu pada Tri Dharma Perguruan Tinggi yang meliputi kegiatan-kegiatan pendidikan (proses belajar mengajar), penelitian dan pengabdian kepada masyarakat. Dalam Tri Dharma Pendidikan, perlu dievaluasi relevansi program dan jurusan yang ada dalam kebutuhan pembangunan, dalam arti apakah sumber daya manusia yang menghasilkan dapat diserap oleh kegiatan perekonomian dan pembangunan $^{15}$.

Penyelenggaraan kegiatan pendidikan tinggi didasarkan pada statuta yang merupakan pedoman dasar yang dipakai sebagai acuan untuk merencanakan, mengembangkan program dan penyelenggaraan kegiatan fungsional sesuai dengan tujuan perguruan tinggi yang bersangkutan. Statuta berisi dasar yang dipakai sebagai rujukan pengembangan peraturan umum, peraturan akademik dan prosedur operasional yang berlaku di perguruan tinggi yang bersangkutan.

Sistem Pendidikan Perguruan Tinggi diharapkan merupakan suatu sistem yang memudahkan seseorang menuntut pendidikan

${ }^{14}$ Sofyan, Strategi Meningkatkan Mutu Pendidikan di Perguruan Tinggi, Jurnal Hunafa Vol. 3 No. 3, September 2006: 319-326

${ }_{15}$ M. Roul asmawi, Strategi Peningkatan Lulusan Bermutu di Perguruan Tinggi, Manakara, Sosial Humaniora, Vol. 9, No 2, Desember 2005. 
tinggi sesuai dengan bakat, minat dan tujuannya, meskipun dengan tetap mempertahankan persyaratan - persyaratan pendirian program studi yang bersangkutan.

\section{Urgensi Interkoneksi Agama dan Sains}

Ide tentang paradigma interkoneksi agama dan sains sebagai bagian dari upaya mempertemukan antara ilmu agama dan ilmu umum tampil memukau dan mencoba untuk memecahkan kebuntuan dari problematika kekinian. Dengan gagasan ini, berbagai disiplin keilmuan itu tidak hanya sampai pada sikap single entity (arogansi keilmuan: merasa satu-satunya yang paling benar), isolated entities (dari berbagai disiplin keilmuan terjadi "isolasi", tiada saling tegur sapa), melainkan sampai pada interconnected entities (menyadari akan keterbatasan dari masing-masing disiplin keilmuan, sehingga terjadi saling kerjasama dan bersedia menggunakan metodemetode walaupun itu berasal dari rumpun ilmu yang lain) ${ }^{16}$.

Tujuan dari interkoneksi agama dan sains ini pada hakikatnya adalah memahami kehidupan manusia yang kompleks secara terpadu dan menyeluruh sehingga muncul keselarasan dan kesepahaman, seperti termaktub dalam Q.S. Al-Mujadilah: 11

Hai orang-orang beriman apabila dikatakan kepadamu: «Berlapang-lapanglah dalam majlis», maka lapangkanlah niscaya Allah akan memberi kelapangan untukmu. Dan apabila dikatakan: "Berdirilah kamu», maka berdirilah, niscaya Allah akan meninggikan orang-orang yang beriman di antaramu dan orang-orang yang diberi ilmu pengetahuan beberapa derajat. Dan Allah Maha Mengetabui apa yang kamu kerjakin.

Paradigma interkoneksi pada hakikatnya ingin menunjukkan bahwa antara berbagai bidang keilmuan baik umum maupun agama sebenarnya saling memiliki keterkaitan, karena memang yang dibidik oleh seluruh disiplin keilmuan tersebut adalah realitas

${ }^{16}$ Siswanto, Perspektif Amin Abdullah Tentang Integrasi Interkoneksi Dalam Kajian Islam, dalam Jurnal Teosofi-Volume 3 Nomor 2 Desember 2013, 379 
alam semesta yang sama, hanya saja dimensi dan fokus perhatian yang dilihat oleh masing-masing disiplin berbeda.

Muara dari interkoneksi agama dan sains yang digagas mensyaratkan dialektika antara variabel-variabel tersebut dalam sistem pendidikan di Indonesia ${ }^{17}$, merupakan usaha untuk menyatukan dan menjadikan sebuah keterhubungan antara nilainilai agama dengan keilmuan umum, sebagai upaya membentuk embrio-embrio intelektual yang mampu membumikan nilai-nilai al-Qur'an dan as-Sunnah dalam kehidupan sehari-hari.

Oleh karena itu rasa superior, eklusifitas, pemilahan secara dikotomis terhadap bidang-bidang keilmuan hanya akan merugikan diri sendiri, baik secara psikologis maupun secara ilmiah akademis. Betapapun setiap orang ingin memiliki pemahaman yang lebih utuh dan komprehensif, bukannya pemahaman yang parsial dan reduktif. Maka dengan menimbang asumsi ini seorang ilmuwan perlu memiliki visi interkoneksi. Mengkaji satu bidang keilmuan dengan memanfaatkan bidang keilmuan lainnya itulah integrasi dan melihat saling keterkaitan antar berbagai disiplin ilmu itulah interkoneksi ${ }^{18}$.

\section{Landasan Interkoneksi Agama dan Sains di Perguruan Tinggi berbasis Pesantren}

Pendekatan interkoneksi merupakan pendekatan yang tidak akan saling melumatkan dan peleburan antara keilmuan umum dan agama. Agar paradigma interkoneksi agama dan sains ini bukan sekedar bertengger pada ranah konsep saja, maka untuk mewujudkan aktivitas akademik dan keilmuan dengan suasana interkonektif ini, maka diterapkan landasan kuat untuk mengimplementasikan konsep tersebut.

17 Siswanto, Perspektif Amin Abdullab tentang Integrasi Interkoneksi Dalam Kajian Islam, Teosofi: Jurnal Tasawuf dan Pemikiran Islam Volume 3 Nomor 2 Desember 2013

${ }_{18}$ Amin Abdullah, dkk, Islamic Studies dalam Paradigma Integrasi-interkoneksi (Sebuah Antologi), Yogyakarta : Suka Press, 2007), ix 
Adapun landasan-landasan dalam interkoneksi agama dan sains di perguruan tinggi berbasis pesantren adalah ;

1. Landasan Teologis

Landasan teologis merupakan pijakan yang bersifat normatif-teologis dalam memahami suatu persoalan dengan menggunakan ajaran yang bersifat mutlak kebenarannya dan diyakini berasal dari Allah SWT. Landasan teologis tersebut dapat dilihat dalam QS. Yunus : 9

Sesunggubnya orang-orang yang beriman dan mengerjakan amal-amal saleh, mereka diberi petunjuk oleh Tuhan mereka karena keimanannya, di bawah mereka mengalir sungai- sungai di dalam syurga yang penuh kenikmatan.

Ayat tersebut merupakan bukti representatif, mengapa interkoneksi ini diperlukan. Iman, Ilmu, Amal. Sebuah trilogi yang tidak dapat di pisahkan. Saling terkait. Iman tanpa ilmu, sesat. Ilmu tanpa Amal, sesat. Amal tanpa ilmu, taklid. Ketiganya merupakan satu rangkaian sistemik dalam struktur kehidupan manusia. Ketiganya juga tidak dapat dipisahkan satu sama lain, namun selalu saling melengkapo guna menghasilkan sebuah cita-cita besar dalam kehidupan, yaitu rahmatan lil alamin.

2. Landasan filosofis

Landasan filosofis ini merupakan perpaduan antara ilmu agama dan ilmu umum diharapkan mampu memahami corak dan kompleksitas kehidupan manusia. Sebagai mahkluq hidup, manusia bersifat kompleks-multidimensial dalam berbagai aspek dan levelnya. Adanya Keberagaman tersebut merupakan interpretasi dari sebuah keinginan untuk memahami kompleksitas yang dimiliki.

3. Landasan kultural

Landasan Cultural atau budaya mengisyaratkan bahwa budaya sebagai hasil dari cipta dan karsa manusia harus mendapatkan 
perhatian serius dari manusia. Dalam mengembangan interkoneksi agama dan sains, pendidikan tidak boleh mengabaikan aspek potensi budaya lokal (local wisdom). Jika budaya atau potensi lokal tidak dijadikan basis pengembangan keilmuan maka akan terjadi proses elitism ilmu, sehingga ilmu menjadi kurang berfungsi dalam kehidupan nyata.

4. Landasan sosiologis

Landasan sosiologis merupakan dasar sosiologis berkenaan dengan perkembangan, kebutuhan dan karakteristik masyarakat. Sosiologi merupakan analisi ilmiah tentang proses sosial dan pola-pola interaksi sosial di dalam sistem pendidikan. Di sinilah konsep interkoneksi agama dan sains pada pendidikan tinggi berbasis pesantren diharapkan mampu berjalan sesuai dengan perkembangan zaman, tuntutan kebutuhan masyarakat dan mampu memahami karakteristik masyarakat melalui pola-pola interaksi sosial yang islami

5. Landasan psikologi

Landasan psikologi merupakan upaya untuk memahmi informasi tentang kehidupan manusia pada umumnya serta gejala-gejala yang berkaitan dengan aspek pribadi manusia yang bertujuan untuk memudahkan proses pendidikan. Secara psikologis, paradigma interkoneksi agama dan sains ini mampu mengubah menjadi pembacaan secara terpadu dan menyeluruh dalam memperkuat kepribadian manusia. Iman terkait dengan keyakinan, ilmu terkait dengan kognisi dan pengetahuan serta amal terkait dengan praksis dan realitas keseharian yang diaplikasikan secara utuh dan integral.

6. Landasan historis

Landasan historis merupakan pandangan ke masa lalu terkait dengan adanya perkembangan dan perubahan dalam aspek ilmu atau sains dan agama. Ilmu umum mengalami dinamika perkembangan yang cukup pesat, namun mengabaikan normanorma agama dan etika kemanusiaan. Melalui interkoneksi agama 
dan sains ini, diharapkan hubungan ilmu agama dan ilmu umum meningkat dan mampu bersinergi, memperkokoh antara yang satu dengan lainnya.

\section{Metode Penelitian}

Penelitian ini menggunakan metode kualitatif jenis studi kasus dengan rancangan multi situs. Studi kasus dalam penelitian ini merupakan penelitian yang mendalam tentang individu, satu kelompok, satu organisasi, satu program kegiatan, dan sebagainya dalam waktu tertentu. Tehnik pengumpulan data pada penelitian ini dilakukan secara sirkuler dengan menggunakan tiga pendekatan yaitu; 1) pengamatan peran serta (participant observation); 2) wawancara mendalam (indepth interview); dan 3) dokumentasi. Sedangkan analisis data dalam penelitian ini dilakukan melalui; reduksi data, penyajian data, dan penarikan kesimpulan atau verifikasi ${ }^{19}$.

\section{Strategi Interkoneksi Agama dan Sains di ST'T Nurul Jadid dan STIKes Nurul Jadid Paiton Probolinggo}

Strategi interkoneksi agama dan sains yang dilakukan oleh Sekolah Tinggi Tekhnologi (ST'T) Nurul Jadid dan Sekolah Tinggi Ilmu Kesehatan (STIKes) Nurul Jadid Paiton Probolinggo meliputi;

\section{Analisis Internal dan eksternal}

Dalam rangka peningkatan mutu pendidikan perguruan tinggi berbasis pesantren yang berada di pondok pesantren Nurul Jadid Paiton Probolinggo, dan upaya untuk menjadikan agama dan sains terkoneksi dan tidak terdikotomi, maka Sekolah Tinggi Tekhnologi (STT) Nurul Jadid dan Sekolah Tinggi Ilmu Kesehatan (STIKes) Nurul Jadid Paiton Probolinggo terlebih dahulu melakukan analisis internal dan eksternal.

${ }_{19}$ Mathews B. Milles, A. Michael Huberman, Analisis Data Kualitatif, (Jakarta : UI Press, 1992), 20 
Analisis lingkungan internal dan eksternal dilakukan terlebih dahulu sebelum diadakan perumusan (formulasi) interkoneksi agama dan sains yang dilakukan oleh Sekolah Tinggi Tekhnologi (ST'T) Nurul Jadid dan Sekolah Tinggi Ilmu Kesehatan (STIKes) Nurul Jadid Paiton Probolinggo. Tujuan dilakukannya analisis lingkungan internal bagi kedua perguruan tinggi berbasis pesantren tersebut sangat diperlukan sebagai cara untuk mengetahui tentang kelebihan dan kekurangan dalam pelaksanaan pendidikan yang telah dilakukannya selama ini, mulai dari kualitas sumber daya manusianya, proses pelaksanaan pendidikannya, in put dan out putnya, kelengkapan sarana pra saranya, sumber keuangannya, manajemen yang digunakannya, dan lain sebagainya.

Sedangkan analisis lingkungan eksternal ditujukan untuk mengetahui tentang perubahan yang terjadi di sekitar lingkungan Sekolah Tinggi Tekhnologi (ST'T) Nurul Jadid dan Sekolah Tinggi Ilmu Kesehatan (STIKes) Nurul Jadid Paiton Probolinggo, baik perubahan ekonomi, sosial, politik, untuk dijadikan sebagai landasan dalam mengembangkan pendidikan selanjutnya.

Analisis lingkungan eksternal dan internal yang dilakukan oleh Sekolah Tinggi Tekhnologi (ST'T) Nurul Jadid dan Sekolah Tinggi Ilmu Kesehatan (STIKes) Nurul Jadid Paiton Probolinggo untuk mengintegrasikan Ilmu Sains dan Agama ini menggunakan analisis "SWOT", yang meliputi; Strength (kekuatan), Weakness (kelemahan), Opportunity (peluang), dan Threat (tantangan).

Dalam pelaksanaannya, Sekolah Tinggi Tekhnologi (STT) Nurul Jadid dan Sekolah Tinggi Ilmu Kesehatan (STIKes) Nurul Jadid Paiton Probolinggo terlebih dahulu membaca situasi, kondisi dan keadaan di dalamnya dan lingkungan sekitarnya untuk melaksanakan seluruh program yang akan direalisasikan. Oleh karena itu, segala pelaksanaan analisis internal dan eksternal dilaksanakan dengan penuh kehati-hatian dan sungguh-sungguh.

\section{Penetapan Visi dan Misi}


Setelah Sekolah Tinggi Tekhnologi (STT) Nurul Jadid dan Sekolah Tinggi Ilmu Kesehatan (STIKes) Nurul Jadid Paiton Probolinggo melakukan analisis internal dan eksternal dalam rangka integrasi keilmuannya, maka langkah selanjutnya adalah menerjemahkan hasil analisis tersebut ke dalam rumusan visi dan misi yang dikembangkan di dalamnya.

Visi dan misi tersebut ditujukan untuk menentukan arah dan tujuan pendidikan yang berlangsung di dalamnya menjadi jelas dan sistematis. Dari landasan penetapan visi dan misi pada kedua perguruan tinggi tersebut, menunjukkan bahwa terdapat tujuan yang jelas dalam mengembangkan institusi kelembagaan melalui integrasi keilmuan agama dan sains.

\section{Mindset Change (Perubahan Pola Pikir)}

Dalam rangka mewujudkan interkoneksi agama dan sains di Sekolah Tinggi Tekhnologi (STT) Nurul Jadid dan Sekolah Tinggi Ilmu Kesehatan (STIKes) Nurul Jadid Paiton Probolinggo, diperlukan perubahan mindset atau pola pikir dari seluruh civitas akademika di lingkungan kampus.

Upaya mengintegrasikan ilmu dan agama selama ini tampaknya dirasakan sebagai suatu hal yang sulit dilakukan. Ilmu yang sesungguhnya tidak lain adalah hasil dari kegiatan observasi, eksperimen, dan kerja rasio pada satu sisi dipisahkan dari agama (Islam) yang bersumber kitab suci al-Qur'an dan al-Hadis. Oleh karena ilmu pengetahuan sesungguhnya hanyalah merupakan hasil temuan manusia dari pergulatan penelitiannya dan karenanya, tingkat kebenarannya bersifat relative dipisahkan dari al- Qur'an dan al-Sunnah yang memiliki kebenaran mutlak.

Pengetahuan ilmiah maupun pengetahuan wahyu pada hakekatnya memiliki fungsi yang sama, yaitu untuk memahami alam dan kehidupan ini. Keduanya berfungsi untuk menyingkap tabir rahasia alam atau sosial yang dibutuhkan oleh umat manusia untuk memenuhi kebutuhan dan meraih kebahagiaan hidupnya. 
Mengembangkan konsep interkoneksi agama dan sains di tengah-tengah tradisi atau budaya masyarakat dan perguruan tinggi, dalam bentuknya seperti sekarang ini, tentu tidak mudah.

Dari hasil wawancara tersebut di atas, dapat diketahui bahwasanya pola pikir dari seluruh civitas akademika untuk memajukan Sekolah Tinggi Tekhnologi (STT) Nurul Jadid dan Sekolah Tinggi Ilmu Kesehatan (STIKes) Nurul Jadid Paiton Probolinggo melalui konsep interkoneksinya harus terus menerus diarahkan pada hal yang positif, terbuka, kebersamaan dan berkomitmen terhadap pencapaian tujuan institusi

\section{Penguatan Kualitas Sumber Daya Manusia}

Interkoneksi Agama dan Sains di Sekolah Tinggi Tekhnologi (ST'T) Nurul Jadid dan Sekolah Tinggi Ilmu Kesehatan (STIKes) Nurul Jadid Paiton Probolinggo dilakukan melalui penguatan kualitas sumber daya manusia secara terencana dan sistematis. Sumber daya manusia yang berkualitas merupakan factor penentu terhadap keberhasilan program Sekolah Tinggi Tekhnologi (ST'T) Nurul Jadid dan Sekolah Tinggi Ilmu Kesehatan (STIKes) Nurul Jadid Paiton Probolinggo dalam mencapai visi dan misi institusi. Untuk mewujudkan kualitas sumber daya manusia yang handal dalam rangka interkoneksi agama dan sains, maka langkah-langkah strategis dilakukan oleh pimpinan pada dua perguruan tinggi tersebut.

Target tersebut tentunya sangat beralasan, mengingat pimpinan Sekolah Tinggi Tekhnologi (STT) Nurul Jadid dan Sekolah Tinggi Ilmu Kesehatan (STIKes) Nurul Jadid Paiton Probolinggo memiliki himmah yang sangat kuat untuk memajukan lembaga melalui peningkatan kualitas sumber daya manusia yang handal dan melahirkan karya-karya inovatif yang berguna bagi pengembangan keilmuan.

Upaya-upaya untuk memenuhi tuntutan kebutuhan dosen dimaksudkan agar berdampak positif bagi peningkatan motivasi kerja mereka dan agar mereka tidak setengah hati lagi dalam 
menunaikan tugas-tugasnya, baik sebagai pendidik maupun sebagai pengembang ilmu pengetahuan. Para dosen dan juga tenaga administrasi tidak selayaknya dituntut hanya menunaikan kewajiban; tetapi harus diimbangi dengan pemenuhan hak-hak kesejahteraan mereka.

Untuk mengatasi problematika kualitas sumber daya manusia saat ini, maka solusi alternative yang dilakukan Sekolah Tinggi Tekhnologi (STT) Nurul Jadid dan Sekolah Tinggi Ilmu Kesehatan (STIKes) Nurul Jadid Paiton Probolinggo terkait dengan kendala utama yaitu mensiasatinya dengan penguatan komitmen kerja, caranya adalah; tenaga-tenaga administrasi bisa juga berkontribusi dalam pembelajaran tetapi hal ini ada konsekuensi yang harus ditanggung.

\section{Pembentukan Budaya Relegius}

Strategi interkoneksi agama dan sains di Sekolah Tinggi Tekhnologi (STT) Nurul Jadid dan Sekolah Tinggi Ilmu Kesehatan (STIKes) Nurul Jadid Paiton Probolinggo dilakukan melalui penciptaan iklim dan budaya kampus yang kondusif. Untuk membangun kebersamaan, integritas dan juga komitmen bersama maka budaya birokrasi yang berkembang selama ini diubah menjadi budaya juang atau dikembangkan ruhul jihad untuk mewujudkan cita-cita luhur bersama.

Format baru yang dikembangkan oleh ST'T dan STIKes untuk mengimplementasikan konsep integrasi agama dan ilmu itu dilakukan secara menyeluruh. Pendidikan tinggi tidaklah cukup dihuni oleh orang-orang yang bekerja setengah hati, dikelola dan dipimpin secara asal-asalan, dan didukung oleh baik perangkat keras maupun perangkat lunak seadanya. Sekalipun dahulunya hal itu memang demikian keadaannya, maka untuk memperkuat usaha mengimplementasikan konsep baru itu seluruh aspeknya harus diubah.

Orientasi pengembangan perilaku kebersamaan, komitmen dan prinsip kerja dimaksud harus menjadi tekanan utama, sehingga 
pantas dibuatkan semacam prasasti, agar setiap orang selalu ingat dan menjadikannya sebagai pegangan oleh semua warga kampus.

Implikasi dari Interkoneksi Agama dan Sains di STT Nurul Jadid dan STIKes Nurul Jadid Paiton Probolinggo

Implikasi dari interkoneksi agama dan sains di STT dan STIKes Nurul Jadid adalah teratasinya kesenjangan dikhotomi keilmuan yang ada. Melalui paradigma interkoneksi yang diaplikasikan dalam kegiatan akademik di STT dan STIKes Nurul Jadid mampu menjembatani kesenjangan yang tajam antara agama dan sains.

Melalui paradigma interkoneksi agama dan sains yang dikembangkan di STT dan STIKes Nurul Jadid, melahirkan sikap inklusif dari seluruh civitas akademika, baik dari unsur pimpinan, dosen, karyawan dan mahasiswa. Pola pikir civitas akademika di STTT dan STIKes Nurul Jadid menjadi lebih terbuka dalam mengembangkan keilmuannya dan menghadapi berbagai problematika yang ada.

Sementara itu implikasinya dalam aspek pendidikan sosial keagamaan, dengan paradigma interkoneksi, para civitas akademika di STT dan STIKes Nurul Jadid diajak untuk berfikir holistik dan tidak parsial dalam menghayati kemejemukan (multicultural) yang ada.

Terciptanya atmosfir akademik yang holistic dan tidak parsial di ST'T dan STIKes Nurul Jadid dengan adanya paradigma interkoneksi agama dan sains dalam konteks keilmuan antara transmitted knowledges dan acquired knowledges diharapkan tercipta atmosfir akademik yang holistik dan tidak parsial. Sehingga sekatsekat spesialisasi bidang pengetahuan tertentu tidak mengakibatkan terbentuknya wawasan miopik-narsistik, dan jangkauan pengetahuan juga tidak membatasi diri pada fakta atau pengenalan finalitas yang bersifat imanen, yang segala sesuatunya hanya dilihat pada makna "pragmatisnya". Akan tetapi juga keberadaan 
makna atau finalitas ilmu pengetahuan yang bersifat transenden, yakni sesuatu yang berada diluar (beyond) sains yang merupakan signifikansi dan arah sesuatu dalam pengertian "teleologisnya".

Berangkat dari hal tersebut di atas, dapat diketahui bahwa interkoneksi agama dan sains yang dikembangkan oleh STT dan STIKes Nurul Jadid mampu menunjukkan hasil yang maksimal dan positif. Paradigma interkoneksi harus mendapatkan perhatian dan pengawalan dari seluruh civitas akademika, agar supaya visi dan misi mulia institusi dapat terwujud, sehingga mutu STT dan STIKes Nurul Jadid dapat terangkat dan memiliki daya saing yang kuat di tengah persaingan dunia pendidikan tinggi dewasa ini.

\section{B. Simpulan}

Interkonsesi agama dan sains sebagai upaya untuk mengawinkan dua disiplin ilmu yang berbeda merupakan langkah strategis dalam membentuk wajah pendidikan dan pembelajaran yang holistic. Konsep ini lahir untuk menjawab adanya sorotan terhadap pelaksanaan pendidikan yang terkotak-kotak, sehingga kurang utuh dalam melahirkan out put peserta didik.

Dengan adanya interkoneksi ini, masing-masing disiplin ilmu selalu terbuka ruang untuk berdialog, berkomunikasi dan berdiskusi dengan disiplin ilmu lainnya, sehingga proses pendidikan dan pembelajaran dengan sistem integrative ini akan melahirkan manusia yang berilmu, beriman, unggul, kompetitif, professional dan berakhlakul karimah. 


\section{DAFTAR PUSTAKA}

Abdul Qadir Djaelani, Peran Ulama dan Santri dalam Perjuangan Politik di Indonesia, (Surabaya : PT. Bina Ilmu, 1994).

Abudin Nata, Sejarah Pertumbuhan dan Perkembangan Lembaga-lembaga Pendidikan Islam di Indonesia, (Jakarta : Grasindo, 2001).

Ahmad Muthohar, Ideologi Pendidikan Pesantren : Pesantren di Tengah Arus Ideologi-ideologi Pendidikan, (Semarang : Pustaka Rizki Putra, 2007).

Amal Fathullah Zarkasyi, "Pondok Pesantren sebagai Lembaga Pendidikan dan Dakwah”, (Jakarta: Gema Insani Pers, 1998).

Amin Abdullah, dkk, Islamic Studies dalam Paradigma Integrasiinterkoneksi (Sebuah Antologi), Yogyakarta : Suka Press, 2007).

Dawam Raharjo, Pesantren dan Pembaharuan, (Jakarta: LP3ES, 1995).

Departemen Pendidikan Nasional, Kamus Besar Bahasa Indonesia, edisi ke-3, (Jakarta : Balai Pustaka, 2003).

Djamaluddin dan Abdullah Aly, Kapita Selekta pendidikan Islam, (Bandung : Pustaka Setia, 1999).

Dwi Priyanto, Inovasi Kurikulum Pesantren Memproyeksikean Model Pendidikan Alternatif Masa Depan), Ibda ' Jurnal Studi Islam dan Budaya, | Vol. 4 | No. 1 | Jan-Jun 2006.

Hasbullah, Kapita Selesta Pendidikan Islam di Indonesia, (Jakarta : PT. Raja Grafindo Persada, 1996).

M. Amin Abdullah, Islamic Studies dalam Paradigma Integrasi Interkoneksi, (Yogyakarta : SUKA Press, 2006).

M. Roul asmawi, Strategi Peningkatan Lulusan Bermutu di Perguruan Tinggi, Manakara, Sosial Humaniora, Vol. 9, No 2, Desember 2005.

Mathews B. Milles, A. Michael Huberman, Analisis Data Kualitatif, (Jakarta : UI Press, 1992). 
Muhammad Heriyudanta, Modernisasi Pendidikan Pesantren Perspektif Azynumardi Ažra, Mudarrisa, Jurnal Kajian Pendidikan Islam, Vol. 8, No. 1, Juni 2016.

Mulyono, Model Integrasi Sains dan Agama dalam Pengembangan Akademik Keilmuan UIN, dalam Jurnal Penelitian Keislaman, Vol. 7, No. 2, Juni 2011.

Nurcholish Madjid, Bilik-Bilik Pesantren Sebuah Potret Perjalanan (Jakarta: Paramadina, 1997).

Siswanto, Perspektif Amin Abdullah Tentang Integrasi Interkoneksi Dalam Kajian Islam, dalam Jurnal Teosofi-Volume 3 Nomor 2 Desember 2013.

Sofyan, Strategi Meningkatkan Mutu Pendidikan di Perguruan Tinggi, Jurnal Hunafa Vol. 3 No. 3, September 2006.

Zainal Abidin Bagir, dkk., (Eds)., Integrasi Ilmu dan Agama: Intrepretasi dan Aksi (Bandung: PT Mizan Pustaka Kerjasama dengan UGM dan Suka Press Yogyakarta, 2005). 
